\title{
Summary Judicial Proceedings as a Measure for Electoral Disinformation: Defining the European Standard
}

\author{
Adam Krzywoń* (1) \\ Faculty of Law and Administration, University of Warsaw, Warsaw, Poland and German Research Institute for Public \\ Administration, Speyer, Germany \\ *Corresponding author: adam.krzywon@gmail.com
}

(Received 21 July 2020; accepted 19 October 2020)

\begin{abstract}
Electoral disinformation has become one of the most challenging problems for democratic states. All of them are facing the phenomenon of - both online and offline - dissemination of false information during preelectoral period, which is harmful for individual and collective rights. As a consequence, some European countries adopted special measures, including summary judicial proceedings in order to declare that information or materials used in electioneering are false and to prohibit its further dissemination. There are already three rulings of the ECtHR concerning this expeditious judicial examination provided in the Polish law. In December 2018 France passed complex regulation against manipulation of information that include similar mechanisms. This article, basing on the ECtHR's case law and some national experiences, attempts to define the minimal European standard for measures targeted at electoral disinformation, especially judicial summary proceeding. It contains the analysis of the notion of electoral disinformation, defines the state's positive obligations in this sphere, and indicates mayor challenges for the legal framework. The principal argument is that summary judicial proceedings - if adequately designed - cannot be questioned from the Convention standpoint and provide a partial solution to the problem of electoral disinformation.
\end{abstract}

Keywords: Electoral disinformation; summary judicial proceedings; European Court of Human Rights; freedom of expression; free elections

\section{A. Introduction}

The phenomenon of electoral disinformation has become one of the most challenging and preoccupying problems for policymakers, courts, and legal scholars. As the manipulation and dissemination of false information online plays an important role in many elections, ${ }^{1}$ some countries

\footnotetext{
${ }^{1}$ See Sanja Kelly, Mai Truong, Adrian Shahbaz, Madeline Earp \& Jessica White, Freedom on the Net 2017: Manipulating Social Media to Undermine Democracy, FrEedom House (2017) https://freedomhouse.org/report/freedom-net/2017/ manipulating-social-media-undermine-democracy. One of the first cases when the global public faced the enormous scale of online disinformation was the US presidential election in 2016. See Hunt Allcott \& Matthew Gentzkow, Social Media and Fake News in the 2016 Election, 31 J. Econ. Persp. 211 (2017). See also Kathleen Hall Jamieson, Cyberwar: How Russian Hackers and Trolls Helped Elect a President: What We Don't, Can't, and Do Know (2018). Other significant examples of this phenomenon were: The 2018 United States midterm elections, the 2016 Brexit referendum, the 2017 French presidential elections, the 2017 German federal elections, the 2018 Italian general elections, and the 2018 Brazilian presidential elections. See Disinformation and Propaganda-Impact on the Functioning of the Rule of Law in the EU and its Member States, Eur. PARL. Doc. (PE 608.864) 39-50 (2019), https://www.europarl.europa.eu/RegData/ etudes/STUD/2019/608864/IPOL_STU(2019)608864_EN.pdf.
}

(C) The Author(s) 2021. Published by Cambridge University Press on behalf of the German Law Journal. This is an Open Access article, distributed under the terms of the Creative Commons Attribution licence (http://creativecommons.org/licenses/by/4.0/), which permits unrestricted re-use, distribution, and reproduction in any medium, provided the original work is properly cited. 
have adopted special measures that would limit the disruptive effect of these practices on democratic processes and institutions. Until now, perhaps the most advanced and complex legislation has been passed in France, where in December 2018 a law against the manipulation of information was issued. ${ }^{2}$ The French law has obviously gained worldwide attention as it responds to the weaponization of social media and its ability to create a virtual electoral reality. The measures adopted in the French law, including the possibility to issue a judicially expeditious ban on the dissemination of online disinformation and disclosure obligations, reflect the powerful nature of the internet and new media when used as tools to generate false stories, which then enter the public domain under the guise of legitimacy. That said, it is worth noting that some of these mechanisms have also been present in the electoral law of other members of the Council of Europe.

In Poland, for example, a special twenty-four-hour summary judicial proceeding was introduced in 1998. Although it has been successfully used to declare that information or materials used in electioneering, both online and offline, are false, it has not attracted much attention and is generally absent from the current legal scholarship and international reports on electoral disinformation. The implications of the Polish law become even more complex when we consider that in mid-2019, the European Court of Human Rights ("ECtHR" or "Court") ruled that Poland had violated the European Convention on Human Rights ("ECHR" or "Convention") for convicting an applicant in one of these extraordinary twenty-four-hour judicial proceedings. ${ }^{3}$ This decision marked the Court's third ruling finding a breach of the right to freedom of expression (Article $10 \mathrm{ECHR}$ ) because the decisions issued in the expeditious judicial examination amounted to a disproportionate interference and were not necessary in a democratic society. ${ }^{4}$

In this respect, these rulings, together with current scholarship and soft-law instruments of the Council of Europe, may be used as a basis upon which to reconstruct the minimal European positive standard for measures targeted at electoral disinformation, especially summary judicial proceedings. To realize this main aim of the present study, it is necessary to analyze the notion of electoral disinformation and then the judicial practice of the ECtHR concerning freedom of expression, right to free elections, and these extraordinary twenty-four-hour electoral proceedings. Moreover, national regulatory instruments, such as the Polish and French laws, seem to be relevant. The principal argument of this Article is that summary judicial proceedings - if adequately designed - cannot be questioned from the Convention standpoint. Judicial intervention can provide a partial solution to the problem of both online and offline electoral disinformation. Nonetheless, judicial summary proceedings are not a remedy for all types of electoral abuses.

In the first section, this Article sets out how to analyze the concept of disinformation and related terminology; how these phenomena can weaken the power of constitutional states and undermine the protection of fundamental rights; and how to identify the reaction of the international community. This Article's second section seeks to present the European protection of the freedom of expression in the electoral context, including the state's positive obligations towards disinformation. Finally, the third section is dedicated to a comparative look at some

\footnotetext{
${ }^{2}$ Loi 2018-1202 du 22 décembre 2018 relative à la lutte contre la manipulation de l'information [Law 2018-1202 of December 22, 2018 on the fight against the manipulation of information], Journal OfFICIEL DE LA RÉPUBLIQUE Francaise [J.O.] [Official GazetTe of France], Dec. 23, 2018.

${ }^{3}$ Brzeziński v. Poland, App. No. $47542 / 07$ (July 25, 2019), http://hudoc.echr.coe.int/eng?i=001-194958.

${ }^{4}$ See Kwiecień v. Poland, App. No. 51744/99 (Jan. 9, 2007), http://hudoc.echr.coe.int/eng?i=001-78876; Kita v. Poland, App. No. 57659/00 (July 8, 2008), http://hudoc.echr.coe.int/eng?i=001-87424. It is necessary to also mention the judgment Jezior v. Poland, App. No. 31955/11 (June 4, 2020), http://hudoc.echr.coe.int/eng?i=001-202614, in which the applicant was convicted in summary judicial proceedings. The Court found that it amounted to a disproportionate interference with the freedom of expression and was not necessary in a democratic society. Nonetheless, in this case, the main issue was the liability of the person who ran a blog for the content posted by third parties, not the nature of the electoral proceedings. The Court's conclusion was that holding him liable for false anonymous comments about the candidate in local elections was not compatible with Article 10 of the ECHR, as he was only an intermediary and had put in place adequate measures in order to detect potentially illegal content.
} 
national legislative responses within the member states of the Council of Europe and includes an analysis of recent ECtHR case law concerning summary judicial proceedings against electoral disinformation in Poland. That section also determines the minimal European standard for these proceedings and explains how they should be configured in light of the Convention.

\section{B. What is Electoral Disinformation?}

\section{The All-Encompassing Term "Fake News" and its Misuse}

Where democracy and fundamental rights are concerned, it is crucial to first clearly define and employ precise terms when evaluating a state's positive actions and when seeking to adopt appropriate legal measures. ${ }^{5}$ Moreover, in Brzeziński v. Poland, the ECtHR referred for the very first time to the notion of "fake news." The Court noted that the summary nature of the judicial electoral proceedings established by Polish statutory law is justified by the need to ensure that "fake news" and statements that harm the reputation of the candidates, as well as those which are likely to distort the result of elections, are rectified as soon as possible. ${ }^{6}$

The Court's determination that the spread of false information in electoral processes can be considered detrimental to democracy is a positive development. That said, one might anticipate that a professional body such as the ECtHR would employ a more sophisticated and clear terminology. It has to be kept in mind, however, that both legal scholarship as well as international organizations reject the term "fake news" as being too vague and inadequate for describing the complex phenomena of untruthful information campaigns. "Fake news" is not a homogenous concept and it can manifest in different ways. ${ }^{7}$ It encompasses a broad spectrum of information types, from low-risk (honest mistakes or inadvertent sharing of false information) to high-risk (malicious fabrications, including textual content and convincing fake audio and/or video content, so called "deep fakes" produced by artificial intelligence or even simple programs that allow users to superimpose images and videos onto unrelated images or videos). Moreover, some politicians have appropriated this broad notion in order to dismiss independent media coverage that they find disagreeable. ${ }^{8}$

In this respect, in both legal scholarship and case law it is preferable to use the term "disinformation" in order to describe false, inaccurate, or misleading information that is designed, presented, and promoted to intentionally cause public harm. ${ }^{9}$ Such information can be understood as being created and distributed with the express intent to threaten and undermine the democratic political processes and rights of others, and possessing a clear political/ideological and/or economic goal. This phenomenon is not restricted in its scope, though it has been found to intensify both before and during democratic decision-making processes. ${ }^{10}$ Disinformation should also be distinguished from misinformation, which is an accidental sharing of false information, and could be the result of an honest mistake or negligence. ${ }^{11}$ Disinformation obviously does not include reporting errors or weak reasoning in political or electoral debate.

The element of intentional harm is crucial in the definition of disinformation. It is decisive as far as interference in the freedom of expression (Article 10.2 ECHR) and positive state actions are

\footnotetext{
${ }^{5}$ Fernando Nuñez, Disinformation Legislation and Freedom of Expression, 10 U.C. Irvine L. Rev. 783,785 (2020).

${ }^{6}$ Brzezinski, App. No. 47542/07 at para. 35.

${ }^{7}$ Irini Katsirea, "Fake News:" Reconsidering the Value of Untruthful Expression in the Face of Regulatory Uncertainty, $10 \mathrm{~J}$. MEdia L. 159, 166 (2018).

${ }^{8}$ Eur. Comm'n, A Multi-Dimensional Approach to Disinformation: Report of the Independent High Level Group on Fake News and Online Disinformation, (2018), https://ec.europa.eu/digital-single-market/en/news/final-report-high-level-expertgroup-fake-news-and-online-disinformation.

${ }^{9}$ Claire Wardle \& Hossein Derakhshan, Information Disorder: Toward an Interdisciplinary Framework for Research and Policymaking, COUnCIL OF EUROPE (2017) https://rm.coe.int/information-disorder-toward-an-interdisciplinary-frameworkfor-researc/168076277c; EUR. PARL., supra note 1, at 131.

${ }^{10}$ Jean-Baptiste Jeangene Vilmer, AleXandre Escorcia, Marine Guillaume \& Janaina Herrera, Information Manipulation: A Challenge for Our Democracies 39 (2018).

${ }^{11}$ Don Fallis, What is Disinformation? 63 LiBr. Trends 401, 402 (2015).
} 
concerned. From a Convention point of view, prohibiting, prosecuting, and criminalizing information solely based on its lack of truthfulness seems to be highly problematic. ${ }^{12}$ False information is not illegal per se; it must also be accompanied by individual or collective damage caused by its production and dissemination. Article 10 of the ECHR does not prohibit discussion or further distribution of information received even if it is strongly suspected that this information might not be truthful. To suggest otherwise, as confirmed by the Court, would be to deprive persons of the right to express their views and opinions about statements made in the mass media and would thus place an unreasonable restriction on the freedom of expression. ${ }^{13}$ The best illustration of this doctrine is the ECtHR permitting the criminalization of falsifying history but only under the condition that this kind of expression constitutes an incitement to hatred or intolerance, or if there is evidence of a serious threat to public order. ${ }^{14}$

From the national perspective, it is clear that interference with freedom of expression does not necessarily entirely depend on the falsity or truthfulness of the information, but rather on the harm that it could cause (see, for example, Spanish constitutional doctrine ${ }^{15}$ and constitutional French case $\left.\mathrm{law}^{16}\right)$. As a recent Organization for Security and Co-Operation in Europe ("OSCE") report demonstrates, ${ }^{17}$ existing national criminal laws ban the fabrication and spreading of false statements, by any means, if they endanger the legitimate and protected interests of individuals, the public, and the state.

\section{The Harmful Effect of False Electoral Information}

Against this backdrop, it is clear that intentionally false information, spread before elections, may be considered as having a disruptive or harmful effect on collective or individual interests. Further, a mass proliferation of disinformation could threaten a state's sovereignty and its political independence and undermine the integrity and fairness of elections. As this phenomenon has no territorial boundaries, harm can be perpetrated both by internal and external actors. If the latter become significantly active in obstructing and influencing national electoral processes, this raises questions of whether such actions can be treated as undermining a nation's sovereignty, ${ }^{18}$ and what the proper response by international law should be. ${ }^{19}$ It is also important to note that the purpose of external interference may not necessarily be to damage or otherwise incapacitate the nation's electoral infrastructure, but rather to gather information that can be used as a part of a larger, more comprehensive, or ongoing disinformation campaign designed to undermine the public's trust in democratic and governmental institutions. ${ }^{20}$

For the individual citizen, there are two negative aspects of electoral disinformation. First, from the voter's point of view, such intrusions risk distorting the process by which free opinions are

\footnotetext{
${ }^{12}$ See Katsirea, supra note 7, at 171-79. See also Human Rights Committee, General Comment No. 34, U.N. Doc. GE.1145331, at para 47 (2011) (indicating that as far as comments about public figures are concerned, they should be avoided from rendering unlawful untrue statements that have been published in error but without malice).

${ }^{13}$ Salov v. Ukraine, App. No. 65518/01, para. 113 (Sept. 6, 2005), http://hudoc.echr.coe.int/eng?i=001-70096.

${ }^{14}$ See, e.g., Perinçek v. Switzerland, App. No. 27510/08 (Oct. 15, 2015), http://hudoc.echr.coe.int/eng?i=001-158235.

${ }^{15}$ Cristina P. Chulvi, Noticias Falsas y Libertad de Expresión e Información: El Control de los Contenidos Informativos en la Red, 41 TeOria Y Realidad Constitucional 297, 310-13 (2018).

${ }^{16} \mathrm{See}$ Conseil constitutionnel [CC] [Constitutional Court] decision no. 2018-773 DC, Dec. 20, 2018 (Fr.). Measures against disinformation are legitimate if they protect the credibility of elections. For the analysis of the judgment, see Rachael Craufurd Smith, Fake News, French Law and Democratic Legitimacy: Lessons for the United Kingdom? 11 J. MedIA L. 52, 63-76 (2019).

${ }^{17}$ Andrey Rikhter, International Standards and Comparative National Approaches to Countering Disinformation in the Context of Freedom of the Media, ORG. FOR SEC. \& COOP. IN EuR. 27-42 (July 1, 2019), https://www.osce.org/files/f/ documents/2/1/424451.pdf.

${ }^{18}$ Ashley C. Nicolas, Taming the Trolls: The Need for an International Legal Framework to Regulate State Use of Disinformation on Social Media, 107 German L. J. 36, 37 (2018).

${ }^{19}$ Manuel Rodriguez, Disinformation Operations Aimed at (Democratic) Elections in the Context of Public International Law: The Conduct of the Internet Research Agency During the 2016 US Presidential Election, 47 INT'L J. LEGAL INFO. 149 (2019).

${ }^{20}$ Drew Marvel, Protecting the States from Electoral Invasions, 28 WM. \& MARY BILL RTs. J. 197, 198 (2019).
} 
formed, and therefore can have a negative effect on the manner through which citizens elect their representatives. In a democratic state, there is diversity and contradiction in public debate and participants are entitled to access to contradictory views and to be informed of differing perspectives. ${ }^{21}$ Participants are capable of, and willing to, distinguish truth from falsehood, as well as able to compare conflicting ideas. ${ }^{22}$ Second, there is the impact on candidates running for election. Disinformation can negatively influence their reputation, a value protected by Article 8 ECHR. ${ }^{23}$ Significant false allegations before elections can have far-reaching effects, cause irreparable damage, lower public esteem, and deprive a person of necessary public trust. Another value that is threatened is the equality of opportunities, which is crucial in all electoral processes and protected by the Convention. ${ }^{24}$ Democratic systems demand fair electoral competition as well as the removal of all unfair barriers to the electioneering process. Uncontrolled dissemination of disinformation adversely affects this balance.

\section{Disinformation, Internet-Based Communication, and Populism}

A further important characteristic of currently observed electoral disinformation is the speed of its dissemination, thanks to the use of the internet and social media-digital amplification mechanisms. False stories can easily enter the public domain and have the appearance of legitimacy, in an unprecedented manner, without any checks on their accuracy. The fabrication and spread of disinformation in the digital age is straightforward and the cost is negligible. Those producing it do not have to undertake cross-referencing or fact-checking and there are no investigative or verification burdens like there are for professional news agencies. ${ }^{25}$ Moreover, the very nature of this new media enables it to be used for the purposes of political disinformation, polarization, and societal fragmentation. Personal algorithms, based on a user's previous behavior and preferences, "know a lot." These tools are able to customize information for the distribution of polarizing and false political content. Echo chambers and information cocoons are being created and like-minded people speak only amongst themselves. $^{26}$ These voters have neither the need, nor the instruments, to verify the truthfulness of the electoral information, and this is what makes it so easy to affect their political choices.

In this respect, it seems that the ECtHR is conscious that internet-based communication implies structural differences not present in regular media, and this also has an important influence on the electoral context. Rules governing traditional media cannot be automatically applied to new media. As indicated in Editorial Board of Pravoye Delo \& Shtekel v. Ukraine:

[T] he Internet is an information and communication tool particularly distinct from the printed media, especially as regards the capacity to store and transmit information. The electronic network, serving billions of users worldwide, is not and potentially will never be subject to the same regulations and control. The risk of harm posed by content and communications on the Internet to the ... human rights and freedoms . . . is certainly higher than that posed by the press. ${ }^{27}$

\footnotetext{
${ }^{21}$ Alain Zysset, Freedom of Expression, the Right to Vote, and the Proportionality at the European Court of Human Rights: An Internal Critique, 17 INT'L J. ConsT. L. 230, 236 (2019).

${ }^{22}$ Ari E. Waldman, The Marketplace of Fake News, 20 U. PA. J. ConsT. L. 845, 848, 869 (2018).

${ }^{23}$ See, e.g., Chauvy \& Others v. France, App. No. 64915/01 (June 29, 2004), http://hudoc.echr.coe.int/eng?i=001-61861.

${ }^{24}$ See, e.g., The Communist Party of Russia \& Others v. Russia, App. No. 29400/05, para. 108 (June 19, 2012), http://hudoc. echr.coe.int/eng? $\mathrm{i}=001-111522$.

${ }^{25}$ Nuñez, supra note 5 , at 787.

${ }^{26}$ Cass R. Sunstein, \#Republic: Divided Democracy in the Age of Social Media 13-16 (2017).

${ }^{27}$ Ed. Bd. of Pravoye Delo \& Shtekel v. Ukraine, App. No. 33014/05, para. 63 (May 5, 2011), http://hudoc.echr.coe.int/eng? $\mathrm{i}=001-104685$. See also Węgrzynowski \& Smolczewski v. Poland, App. No. 33846/07, para. 98 (July 16, 2013), http://hudoc. echr.coe.int/eng?i=001-122365.
} 
Similarly, the Court emphasizes the far-reaching harmful effects of hate speech when posted on somebody's Facebook profile. ${ }^{28}$

The last factor - of a political nature - that empowers electoral disinformation is the rising tide of populism. This is particularly important in the Central and Eastern European context, although no democracies are immune to this phenomenon. ${ }^{29}$ Populist rhetoric and disinformation are both highly strategic communicative approaches. Populist politicians present emotional and personal sources of truth as superior to the knowledge gained from science, academic inquiry, or discussion. ${ }^{30}$ According to such populist logic, "the remote elites" — not the "ordinary people" — use science, statistics, and scholarship to hold on to power and preserve their hegemonic position. On the one hand, it may be justly maintained that social media has given a voice to underprivileged groups within society, resulting in greater democratization. But, on the other hand, it has also created opportunities for populist politicians: They are able to use social media to share manipulative content and fulfill particular political interests. ${ }^{31}$

\section{The Reliability of Electoral Information and International Soft-Law Standards}

The harmful effects of the described phenomena make clear why a number of countries and international organizations are concerned with the purity, authenticity, and truthfulness of information disseminated in the media during the pre-electoral decision-making period. States should adopt a proactive approach, because the absence of an adequate legal response towards disinformation could lead to serious consequences, resulting in a loss of public confidence in democratic procedures - the notion of contentious elections. ${ }^{32}$ When human rights and democratic values are at stake, the law cannot lag behind technology. ${ }^{33}$

The state's obligations to adopt legal measures against electoral disinformation have been highlighted in some international soft-law documents. A quick overview of them is useful with regard to the aim of this Article. Recommendations from various international organizations demonstrate how to adequately design laws concerning both false electoral information and summary judicial proceedings.

The European Union ("EU") adopted various soft law instruments in the field ${ }^{34}$ and commissioned a comprehensive study concerning disinformation. ${ }^{35}$ The authors of the latter recommended taking positive measures by regulating both online political advertising and micro-targeting.

\footnotetext{
${ }^{28}$ Beizaras \& Levickas v. Lithuania, App. No. 41288/15, para. 127 (Jan. 14, 2020), http://hudoc.echr.coe.int/eng?i=001200344. See also Fatullayev v. Azerbaijan, App. No. 40984/07, para. 95 (Apr. 22, 2010), http://hudoc.echr.coe.int/eng?i= 001-98401 (pointing out that the internet is a medium which in modern times has no less powerful effect than print media).

${ }^{29}$ See, e.g., Matteo Monti, Italian Populism and Fake News on the Internet: A New Political Weapon in the Public Discourse, in Italian Populism and Constitutional Law: Challenges to Democracy IN the 21st Century 177-97 (Giacomo Delledonne et al. eds., 2020) (describing the Italian experience of the spread of false information in the digital media by populist movements).

${ }^{30}$ James Ball, Post-Truth: How Bullshit Conquered the World 4 (2017).

${ }^{31}$ Sven Engesser, Nayla Fawzi \& Anders Olof Larsson, Populist Online Communication: Introduction to the Special Issue, 20 INFO., COMMC'N \& SOC'Y 1279, 1280 (2017).

${ }^{32}$ See Pippa Norris, Richard W. Frank \& Ferran Martinez i Coma, Contentious Elections: From Ballots to BARRICADES 1-22 (2015).

${ }^{33}$ Jan VAn DiJK, The Network SOCIETY 128 (2006); Molly Land, Toward an International Law of the Internet, HARV. INT'L L.J. 393, 456 (2013).

${ }^{34}$ Eur. Comm'N, supra note 8; Communication from the Commission to the European Parliament, the Council, the European Economic and Social Committee and the Committee of the Regions: Tackling Illegal Content Online: Towards an Enhanced Responsibility of Online Platforms, COM (2017) 555 final (Sept. 28, 2017); Communication from the Commission to the European Parliament, the Council, the European Economic and Social Committee and the Committee of the Regions: Tackling online disinformation: a European Approach, COM (2018) 236 final (Apr. 26, 2018); Resolution on online platforms and the digital single market, EUR. PARL. DOC. 2016/2276(INI) (2017).

${ }^{35}$ Eur. PARL., supra note 1.
} 
Similarly, the Council of Europe has attempted to tackle these phenomena, not only by defining disinformation, but also by proposing a framework for research and policymaking. ${ }^{36}$ The issue of the internet intermediaries' responsibilities has been raised. ${ }^{37}$ The Parliamentary Assembly of the Council of Europe has called upon states to consider actions concerning the accountability of internet operators ${ }^{38}$ and has suggested that all third-party content posted on professional media websites should fall under the editorial responsibility of these media. ${ }^{39}$ The Venice Commission has also issued an exhaustive report on digital technologies and elections, indicating that states have a positive responsibility to prevent undue interference with civil and political rights by third parties. ${ }^{40}$

\section{Freedom of Electoral Expression in Europe \\ 1. Interrelations of Freedom of Expression and Free Elections}

Having examined the notion of disinformation, its negative influence on democratic values, and the related international framework, it is crucial to analyze the general margin of appreciation conferred on national authorities by the ECtHR as far as freedom of expression in the electoral context is concerned. The aforementioned phenomena undoubtedly affect both the right to freedom of expression (Article 10 ECHR) and the right to free elections (Article 3 of Protocol No. 1 to ECHR; "P1-3"). Determining the necessary balance between those two interrelated rights makes it possible to answer the question of how summary judicial electoral proceedings should be configured.

The guarantees arising from both Article 10 and P1-3 are crucial to establishing and maintaining the foundations of an effective and meaningful democracy governed by the rule of law, although they are subject to different interpretative methods adopted by the ECtHR: More activism and a teleological approach towards Article 10 versus restraint and a consensus-based approach with regard to P1-3. ${ }^{41}$ There is undoubtedly a link between these provisions, namely the need to guarantee respect for pluralism of opinion in a democratic society through the exercise of civic and political freedoms. ${ }^{42}$ The state's obligation expressed in P1-3 to create "conditions which will ensure the free expression of the opinion of the people in the choice of the legislature" essentially implies the freedom of expression. The latter has become one of the essential prerequisites for the guarantees established in $\mathrm{P} 1-3 .{ }^{43}$ It is particularly important in the period preceding

\footnotetext{
${ }^{36}$ Wardle \& Derakhshan, supra note 9.

${ }^{37}$ Committee of Ministers, Recommendation CM/Rec(2018)2 of the Committee of Ministers to Member States on the Roles and Responsibilities of Internet Intermediaries, CounCIL OF EUROPE (Mar. 7, 2018), https://search.coe.int/cm/Pages/result_ details.aspx?ObjectID=0900001680790e14.

${ }^{38}$ Parliamentary Assembly, Resolution 1970 (2014) Internet and Politics: The Impact of New Information and Communication Technology on Democracy, CounCIL OF EUROPE (Jan. 29, 2014), https://assembly.coe.int/nw/xml/XRef/ Xref-XML2HTML-en.asp?fileid=20447\&lang=en.

${ }^{39}$ Parliamentary Assembly, Resolution 2143 (2017) Online Media and Journalism: Challenges and Accountability, CounCIL OF EUROPE (Jan. 25, 2017), https://assembly.coe.int/nw/xml/XRef/Xref-XML2HTML-en.asp?fileid=23455\&lang=en.

${ }^{40}$ Venice Commission, Op. no. 925/2018, Joint Report of the Venice Commission and of the Directorate of Information Society and Action Against Crime of the Directorate General of Human Rights and Rule of Law (DGI) on Digital Technologies and Elections, CounCIL OF EUROPE (June 24, 2019), https://www.venice.coe.int/webforms/documents/?pdf= CDL-AD(2019)016-e. Another valuable initiative has been undertaken by the Organization of American States ("OAS") Special Rapporteur on Freedom of Expression, that recognizes the legitimate concern, and the importance of adopting proportional measures against electoral disinformation. The response must not, however, be the establishment of new criminal types to sanction the dissemination of false news, but positive actions aimed at raising public awareness about the existence of disinformation. One of the recommendations is to strengthen judicial proceedings of a civil nature, by making them more efficient and timely, which can become an effective tool to combat disinformation that affects officials and candidates for public office. See Guide to Guarantee Freedom of Expression Regarding Deliberate Disinformation in Electoral Contexts, Inter-Am. Comm'n H.R., Office of the Special Rapporteur on Freedom of Expression (Oct. 2019), http://www.oas.org/en/ iachr/expression/publications/Guia_Desinformacion_VF\%20ENG.pdf.

${ }^{41}$ Zysset, supra note 21 , at 232.

${ }^{42}$ Ždanoka v. Latvia, App. No. 58278/00, para. 115 (Mar. 16, 2006), http://hudoc.echr.coe.int/eng?i=001-72794.

${ }^{43}$ Mathieu-Mohin \& Clerfayt v. Belgium, App. No. 9267/81, para. 54 (Mar 2, 1987), http://hudoc.echr.coe.int/eng?i=00157536.
} 
an election that opinions and information of all kinds-not only that which is favorable, but also that which shocks, offends, and disturbs-are permitted to circulate freely. In the context of electoral debates, the unhindered exercise of freedom of speech by candidates has particular significance. ${ }^{44}$ There is also a strong legitimate public interest to be informed about serious allegations concerning electoral candidates. ${ }^{45}$

The P1-3 is the best example of the ECHR as a living instrument. Initially, its provisions were considered only as an institutional guarantee, but finally it has developed into a fully enforceable individual right. ${ }^{46}$ The scope of application is also variable, as the Court applies it not only to parliamentary elections. ${ }^{47} \mathrm{~A}$ wide margin of appreciation has been granted to the national authorities as far as the configuration of the electoral system is concerned. With regard to the latter, there are numerous ways of organizing and running electoral systems, and a wealth of differences, inter alia, in historical background, cultural diversity, and political thought within Europe. ${ }^{48}$

Moreover, concerning P1-3, the primary obligation is the adoption by the state of positive measures to hold democratic elections. ${ }^{49}$ Unlike Article 10, which principally obliges states to practice abstention and non-interference, in the light of the right to free elections, public authorities should take active steps to organize and efficiently carry out voting so that all ballots are free of any pressure. The states enjoy a margin of appreciation not only when determining the institutional dimension of the electoral system, but also when regulating certain aspects of the freedom of expression in the electoral context. The Court has indeed authorized the adoption of different models of electioneering at the national level, in particular by establishing rules for electoral advertising in the media, as a common approach to this issue has not yet been developed. In this field, a "somewhat wider margin of appreciation than that normally afforded to restrictions on expression on matters of public interest" is allowed. ${ }^{50}$

As far as Article 10 is concerned, the margin of appreciation is quite heterogeneous, and depends on a number of factors - the author, content, form of expression-and their interrelationship. Although, generally speaking, in the case of political expression or debate on a matter of general public interest, the scope of national discretion is rather limited. ${ }^{51}$ The specific circumstances of a case would therefore indicate which margin of appreciation should be accorded: A broad one, related to the institutional electoral system and certain aspects of electioneering such as electoral advertising, or a narrow one, deduced from the privileged position of the freedom of political expression under Article 10. This is a consequence of the aforementioned distinction made in the Court's case law. On the one hand, the ECtHR emphasizes that in the period preceding or during elections, it is legitimate to place certain restrictions, of a type which would not usually be acceptable, on freedom of expression. ${ }^{52}$ Interference with this freedom may be necessary to guarantee pluralism, the proper conduct of public debate, and fair competition between the

\footnotetext{
${ }^{44}$ Orlovskaya Iskra v. Russia, App. No. 42911/08, para. 110 (Feb. 21, 2017), http://hudoc.echr.coe.int/eng?i=001-171525.

${ }^{45}$ Ólafsson v. Iceland, App. No. 58493/13, para. 50 (Mar. 16, 2017), http://hudoc.echr.coe.int/eng?i=001-171974.

${ }^{46}$ Javier Garcia Roca, La Transformacion Constitucional Del Convenio Europeo De Derechos Humanos 79-80 (2019).

${ }^{47}$ The ECtHR recently mentioned the implications of P1-3 in the context of a national referendum. See Magyar Kétfarkú Kutya Párt v. Hungary, App. No. 201/17, para. 99 (Jan. 20, 2020), http://hudoc.echr.coe.int/eng?i=001-200657.

${ }^{48}$ Sitaropoulos \& Giakoumopoulos v. Greece, App. No. 42202/07, paras. 65-66 (Mar. 15, 2012), http://hudoc.echr.coe.int/ eng?i=001-109579; Hirst v. United Kingdom, App. No. 74025/01, para. 61 (Oct. 6, 2005), http://hudoc.echr.coe.int/eng?i= 001-70442.

${ }^{49}$ Mathieu-Mohin \& Clerfayt v. Belgium, App. No. 9267/81, para. 50 (Mar. 2, 1987), http://hudoc.echr.coe.int/eng?i=00157536.

${ }^{50}$ Animal Defenders International v. United Kingdom, App. No. 48876/08, para. 123 (Apr. 22, 2013), http://hudoc.echr.coe. int/eng? $\mathrm{i}=001-119244$.

${ }^{51}$ According to ECtHR case law, all opinions and information disseminated during an electoral period should be treated as part of the debate on matters of public interest. See Filatenko v. Russia, App. No. 73219/01, para. 40 (Dec. 6, 2007), http:// hudoc.echr.coe.int/eng? $\mathrm{i}=001-83830$.

${ }^{52}$ Bowman v. United Kingdom, App. No. 24839/94, para. 43 (Feb. 19, 1998), http://hudoc.echr.coe.int/eng?i=001-58134.
} 
candidates. ${ }^{53}$ On the other hand, the Court points out that the adoption of the wider margin of appreciation under P1-3, when establishing the rules of electioneering, always entails the risk that it could lead to results incompatible with the privileged position of free political speech under Article $10 .^{54}$

Against this backdrop, the general European standard for freedom of expression during electoral campaigns enables national authorities to adopt measures to combat disinformation. As mentioned before, false information, massively disseminated on account of modern technologies, may cause collective and individual harm. There is a pressing social need and a legitimate aim (Article 10.2 ECHR) in ensuring the truthfulness of electoral information. Nonetheless, all remedies must be proportional and there must not be any unjustified curtailment of procedural guarantees. If possible, judicial review of any state action limiting the flow of electoral information should be granted.

\section{Positive Obligations Concerning Freedom of Electoral Expression}

In this context, another important issue arises: Do national authorities also have, in light of the European standard, a positive obligation to provide effective measures against electoral disinformation? To tackle this question, an important reference to current legal scholarship should be made. Some authors reject the strict distinction between positive and negative obligations, indicating that privileging the latter could be anachronistic in contemporary societies. ${ }^{55}$ The non-interference principle in itself does not suffice where structural inequalities are present. In order to effectively guarantee human rights, the individual must also be protected from an abuse of power from other societal actors. The digital environment is indeed a sphere of huge horizontal imbalances where the power of private entities has weakened constitutional states. To suggest otherwise is to not be aware of the paradigm shift brought about by new media: An international concentration of capital and power, combined with the decentralization of production and the creation of a global "flow economy."

According to ECtHR case law, Article 10 implies an obligation by governments to promote the right to freedom of expression and to provide an environment conducive to participation in public debates by all persons concerned, allowing them to express their opinions and ideas without fear. ${ }^{57}$ Although privately-owned media, including newspapers, must be free to exercise editorial discretion when deciding which articles, comments, and letters submitted by private individuals they publish, "exceptional circumstances" may arise in which an editor can legitimately be required to publish, for example, a retraction, an apology, or a judgment in a defamation case. ${ }^{58}$ This "right to reply," considered a positive obligation, ${ }^{59}$ constitutes an effective reaction to false facts and statements, and guarantees proper balance between freedom of expression, public interest to access accurate and truthful information, and reputational rights. ${ }^{60}$ It therefore seems clear that the positive obligation to create an adequate environment for free expression, derived from Article 10, includes the possibility of responding to untruthful statements, especially in cases where collective or individual interests are at stake. National authorities should provide a legal framework for such actions, taking into consideration the inequalities that may arise between societal actors.

\footnotetext{
${ }^{53}$ Animal Defenders International, App. No. 48876/08 at para. 112; Erdoğan Gökçe v. Turkey, App. No. 31736/04, para. 40 (Oct. 14, 2014), http://hudoc.echr.coe.int/eng?i=001-147465.

${ }^{54}$ TV Vest AS \& Rogaland Pensjonistparti v. Norway, App. No. 21132/05, para. 66 (Dec. 11, 2008), http://hudoc.echr.coe. int/eng?i=001-90235; Orlovskaya Iskra, App. No. 42911/08 at para. 111.

${ }^{55}$ Laurens Lavrysen, Human Rights in a Positive State: Rethinking the Relationship Between Positive and Negative Obligations Under the European Convention on Human Rights 305-06 (2016).

${ }^{56}$ VAN DiJK, supra note 33, at 129.

${ }^{57}$ Dink v. Turkey, App. Nos. 2668/07, 6102/08, 30079/08, 7072/09 \& 7124/09, para. 137 (Sep. 14, 2010), http://hudoc.echr. coe.int/eng?i=001-100383.

${ }^{58}$ See Melnychuk v. Ukraine, App. No. 28743/03, para. 2 (July 5, 2007), http://hudoc.echr.coe.int/eng?i=001-70089.

${ }^{59}$ See Felix Hempel, The Right of Reply Under the European Convention on Human Rights: An Analysis of Eker v. Turkey, 10 J. Media L. 17, 28-33 (2018).

${ }^{60}$ Eker v. Turkey, App. No. 24016/05, para. 48 (Oct. 24, 2017), http://hudoc.echr.coe.int/eng?i=001-178387.
} 
Another important positive obligation concerning horizontal relations has to do with the role of the state as a guarantor of pluralism within society. ${ }^{61}$ Democracy, as the only political model contemplated by the Convention, ${ }^{62}$ offers the possibility of resolving a state's problems through dialogue, without recourse to violence, even when the problems are irksome. The essence of democracy is to allow diverse political programs to be proposed and debated, even those that call into question the way in which a state is currently organized. ${ }^{63}$ In the light of Article 10, therefore, in a sensitive sector such as the media, the public authorities have, in addition to their negative duty of non-interference, a positive obligation to put in place an appropriate legislative and administrative framework to guarantee effective pluralism. ${ }^{64}$ The responsibility of the public authorities "as ultimate guarantor of pluralism" has also been recognized under P1-3. The Court requires the adoption of positive measures to organize democratic elections under conditions that will ensure the free expression of the opinion of the people in the choice of the legislature. Public intervention should take place in order to open the media up to different viewpoints. ${ }^{65}$ If the public authorities allow false electoral information to be produced and massively disseminated in the media, without affording legitimate actors_-for example, candidates — any effective measures, pluralism is directly affected. Remaining passive towards disinformation and adopting only a policy of non-interference may also affect the electoral equality of the candidates and the fairness of the electoral process. There is no doubt that substantive political equality can be a basis for positive free speech rights, with an ideal of equal distribution to communicative resources. ${ }^{66}$

\section{Summary Judicial Proceedings as a Reaction Towards Electoral Disinformation: National Experiences and Possible Solutions}

\section{First Examples: Polish Electoral Law and the ECtHR's Reactions}

Since 1998, Polish electoral law ${ }^{67}$ has enabled all candidates standing for election, as well as electoral committee representatives, to initiate special judicial proceedings if disseminated electoral materials such as posters, slogans, leaflets, and statements contain false data or information. The interested party may request that the court assess the truthfulness of these statements and issue an order prohibiting their dissemination. This might also involve the confiscation of such materials and the correction of false information, as well as a ruling that protects his or her individual rights; for example, publication of an answer to statements that violate reputation or an apology to the aggrieved party. It is also possible to demand payment of up to 100,000 złoty (about 25,000 euros) to a charity organization. The petition must be examined by a court in non-contentious civil proceedings within twenty-four hours. The first-instance ruling may be appealed within twenty-four hours from the moment it is pronounced, and the second-instance court must rule within the same time limit. The Electoral Code also stipulates how the court's decision is to be enforced.

On three occasions, the ECtHR has reviewed the practical application of these provisions. All three cases concerned a local election, and the alleged disinformation was disseminated in a traditional

\footnotetext{
${ }^{61}$ LAVRYSEN, supra note 55, at 94.

${ }^{62}$ Refah Partisi (the Welfare Party) \& Others v. Turkey, App. Nos. 41340/98, 41342/98, 41343/98 \& 41344/98, para. 86 (Feb. 13, 2003), http://hudoc.echr.coe.int/eng?i=001-60936.

${ }^{63}$ Manole \& Others v. Moldova, App. No. 13936/02, paras. 95-99 (Sept. 17, 2009), http://hudoc.echr.coe.int/eng?i=001-94075.

${ }^{64}$ Centro Europa 7 S.r.l. \& Di Stefano v. Italy, App. No. 38433/09, para. 134 (June 7, 2012), http://hudoc.echr.coe.int/eng?i= 001-111399.

${ }^{65}$ Communist Party of Russia \& Others v. Russia, App. No. 29400/05, paras. 125-28 (June 19, 2012), http://hudoc.echr.coe. int/eng?i=001-111522.

${ }^{66}$ Jacob Rowbottom, Positive Protection for Speech and Substantive Political Equality, in Positive FreE SPEECH: Rationales, Methods and Implications 25 (Andrew T. Kenyon \& Andrew Scott eds., 2020).

${ }^{67}$ The actual legal basis of the summary judicial proceeding is Article 111 of the Electoral Code from 2011. It replaced previous provisions of different acts concerning parliamentary, presidential, and local elections. All ECtHR judgments analyzed in this section of the Article refer to Article 72 of the Law of 1998 on Elections to Municipal Councils, District Councils, and Regional Assemblies.
} 
manner-in written media or in the form of electoral leaflets. ${ }^{68}$ In the first case, the ECtHR pointed out that electoral proceedings, conducted within very short time-limits, are aimed at ensuring the proper conduct of the electoral campaign by preventing infringements of the candidate's personal rights, which could affect the result of the elections. ${ }^{69}$ The provision of such a summary remedy serves the legitimate aim of ensuring the fairness of the electoral process and, as such, cannot be questioned from the Convention standpoint. The general compliance of the model of electoral court proceedings with the European standard may not, however, result in the undue curtailment of the procedural guarantees afforded to the parties. The Court also noted that the Polish courts in the first and second instances failed to comply with the requirement to hand down a judgment within the twenty-fourhour period. Both rulings were issued after the balloting had taken place, when the extraordinary proceedings had lost their relevance with regard to the claimant's electoral perspectives. Under these circumstances, the courts should have discontinued the case, given the fact that the aggrieved party had the right to start ordinary civil proceedings for the protection of individual rights.

In the second case, the ECtHR noted that the national courts, in their expeditious examination of election-related disputes, had failed to distinguish between statements of fact and value judgments, and had not considered that the impugned material formed part of a debate on matters of public interest. ${ }^{70}$ The Court pointed out that all the rulings concerning false electoral statements were delivered after the local elections_-almost three weeks in the first instance, and eight months in the second-and they were not relevant to the electoral processes. ${ }^{71}$

In the third and most recent judgment, the ECtHR basically repeated its previous arguments. As mentioned above, this ruling referred to the notion of "fake news" which could damage the candidate's reputation and should be rectified as soon as possible to preserve the quality of public debate. The examination of election-related disputes should not, however, curtail the parties' procedural guarantees. ${ }^{72}$ Analyzing the circumstances of the case, the Court indicated that the applicant, a candidate in the municipal elections, made several critical comments about the mayor standing for reelection. Further, the Court pointed out that the electoral campaign was undoubtedly the most appropriate moment to make such allegations public. In this context, the Court did not share the national courts' point of view that the alleged accusation, which was of a political nature, had gone beyond acceptable forms of electoral propaganda. ${ }^{73}$ As far as sanctions were concerned, the ECtHR emphasized their cumulative character. Simultaneously ordering the prohibition of the electoral material's further dissemination, the obligation to publish an apology in the front pages of two local newspapers, and the payment of 5,000 złoty (about 1,200 euros) to a charity organization was deemed to be disproportionate, and the Court suggested that such sanctions could have a chilling effect on other candidates running in the local elections. ${ }^{74}$

\section{Second Phase: French Law and the Digital Environment: Other National Examples}

In December 2018, France adopted legislation expediting electoral proceedings and introducing higher transparency requirements for political advertising on social media. ${ }^{75}$ The fight against electoral disinformation has entered the second phase, because the French law recognizes the

\footnotetext{
${ }^{68}$ In Jezior, the applicant was held liable in the electoral judicial proceedings for third-party comments posted on his blog. See Jezior v. Poland, App. No. 31955/11 (Mar. 4, 2009), http://hudoc.echr.coe.int/app/conversion/pdf/?library=ECHR\&id= 001-152345\&filename=001-152345.pdf\&TID=ihgdqbxnfi. Nonetheless, in Jezior, the main issue was not the nature of the electoral proceedings but the internet intermediary liability and his obligation to put in place adequate measures to detect potentially illegal content. See supra note 4 and accompanying text.

${ }^{69}$ Kwiecień, App. No. $51744 / 99$ at para. 55.

${ }^{70}$ Kita, App. No. $57659 / 00$ at paras. $44-46$.

${ }^{71} I d$. at para. 50 .

${ }^{72}$ Brzeziński, App. No. $47542 / 07$ at paras. 35, 55.

${ }^{73} I d$. at para. 57.

${ }^{74} I$ d. at para. 61.

${ }^{75}$ See supra notes 2 and 16 and accompanying text.
} 
importance of the digital environment and internet-based communication for this harmful phenomenon. $^{76}$

Generally speaking, there are three fundamental mechanisms provided for in the French law against manipulation of information. First, there is a set of obligations for online platform operators, who should implement measures to combat the dissemination of false information likely to disturb public order and electoral processes. They are obligated to establish an easily accessible and visible mechanism enabling their users to report such information. Moreover, the transparency of the algorithms used for recommending, classifying, or referencing informational content should be ensured, and accounts that massively promote false news are to be monitored. When it comes to financial aspects, three months prior to an election, online platforms must provide users with details concerning the identity of actors who finance the promotion of content related to the debate of general interest. Information about remuneration received in return for the promotion of such content must be made public.

Second, the French law calls for special judicial proceedings to halt the spread of online disinformation within three months prior to elections. A wide range of actors, including ministère public (public prosecutors), candidates, political parties, and persons who have a legal interest, may petition the court for an order that prohibits its dissemination. The court must issue a ruling within forty-eight hours when inaccurate or misleading allegations or imputations of fact, able to affect forthcoming elections, are deliberately, artificially, or automatically disseminated on a mass scale through an online public communication service (Article L 163-2 of the Electoral Code). In practice, to prohibit such dissemination, the manifest falsity of the claim must be established before the court. There should not be any evidence to the contrary, the transmission of the false information has to be deliberate, and the content must influence voters and affect the reliability of the forthcoming election. ${ }^{77}$ An appeal is possible, but the appellate court is also required to issue its ruling within forty-eight hours.

Third, the French law provides measures against foreign state propaganda. If false information which could affect the electoral process is deliberately disseminated, the administrative authority can suspend a broadcasting service controlled by another state.

A brief mention of German legislation is also relevant. Because Germany was the first state to provide complex regulation against illegal online content ${ }^{78}$ some scholars claim that there is "an anti-fake news law" that "penalizes social media networks for harboring false and hateful content in their platforms."79 Others consider that the regulation "gave teeth" to existing criminal sanctions by imposing heavy fines on social media platforms that fail to speedily delete "fake reports and hate speech." ${ }^{80}$ Indeed, German law protects social media users and obligates the platforms to provide measures in order to report problematic content. Nonetheless, it does not create any new legal offenses such as "hate speech" or "fake news" and refers to the existing definitions of crimes under the German Criminal Code. There is a long list of illegal content, mostly undermining public safety and general interests, that must be deleted by social media operators. ${ }^{81}$ Although the battle against disinformation was one of the main arguments for adopting the law, the notion does not appear in the law itself; ${ }^{82}$ the closest offense is the dissemination of propaganda material

\footnotetext{
${ }^{76}$ Amélie Heldt, Let's Meet Halfway: Sharing New Responsibilities in a Digital Age, 9 J. InFo. Pol’y 336, 346 (2019).

${ }^{77} I d$. at $56-58,61,69-71$.

${ }^{78}$ Netzwerkdurchsetzungsgesetz [NetzDG][The Network Enforcement Act], Sept. 1, 2017, BundESGESETZBLATT [BGBL] (Ger.).

${ }^{79}$ Juan Carlos Escudero de Jesús, Fake News and the Systemic Lie in the Marketplace of Ideas: A Judicial Problem?, 87 Revista JuRIDICA U. P.R. 1394, 1395, 1413 (2018).

${ }^{80}$ Katsirea, supra note 7 , at 159.

${ }^{81}$ See Wolfgang Schulz, Regulating Intermediaries to Protect Privacy Online-the Case of the German NetzDG, 1 HIIG DisCUSSION PAPER SERIES 5 (2018), https://www.hiig.de/wp-content/uploads/2018/07/SSRN-id3216572.pdf.

${ }^{82}$ See Thomas Wischmeyer, "What is Illegal Offline is Also Illegal Online"-The German Network Enforcement Act 2017, in Fundamental Rights Protection Online: The Future Regulation of Intermediaries 44 (Byliana Petkova \& Tuomas Ojanen eds., 2020).
} 
by unconstitutional organizations. As the German law obligates social media and other internet platforms to fight continuously against illegal online content, it does not have a direct electoral dimension. Regulated offenses do not relate specifically to pre-election false information. ${ }^{83}$ Moreover, it introduces reliance on private companies to identify and remove problematic content, so generally speaking, judicial intervention is not required.

\section{How Should Summary Judicial Proceedings Against Electoral Disinformation be Configured? Specific and in abstracto Models}

Previous sections of this Article illustrated that current standards of European human rights protection enable one to point out the existence of a state's positive obligations which seek to safeguard electoral pluralism and combat false information (P1-3 and Article 10). This is particularly important in the changing online environment, which creates a breeding ground for disinformation campaigns. The national legal framework should reflect this digital reality, although, as the Polish example shows, basic measures such as summary judicial proceedings may be formulated in rather general terms, covering both online and offline false electoral information. Moreover, it seems that the simple penalization of false statements is insufficient. This traditional form of law enforcement, as the aforementioned OSCE report shows, ${ }^{84}$ exists in almost every European country and is no longer effective. Similarly, the fact that the decision to initiate prosecution depends on the public authorities-rather than on a candidate, political party, or other private actor-implies a risk of unequal and selective application. With regard to electoral disinformation, as it is unlikely that criminal proceedings will be concluded prior to election day, all subsequent procedural rights should be fully-guaranteed and expeditious examinations of criminal charges can be questioned from the Convention standpoint.

Against this backdrop, measures such as the Polish and French summary judicial proceedings, which are of a civil nature, seem to be a more adequate reaction, and move towards the aforementioned positive obligations. Generally speaking, a court's assessment of the truthfulness of electoral information, when the basic sanction is an order to stop its dissemination or to apologize to the aggrieved party, constitute a legitimate interference in the political electoral discourse. Obviously, the legal framework for these proceedings should be properly defined, according to the aforementioned margin of appreciation conferred on the national authorities by Article 10 and P1-3, and its practical application must also respect the general rules for the protection of freedom of expression established in ECtHR case law.

Summary judicial proceedings can target either the author of electoral disinformation or its mass dissemination. As the analysis of the Polish and French laws has shown, there are two theoretical models: A specific review, where the author of the false information is known, initiating a kind of inter partes proceeding, or an in abstracto one, which is more viable if the author is not known, and seems to be more applicable to the online environment. The latter reflects one of the main characteristics of online speech, namely, its anonymity. ${ }^{85}$ The in abstracto model appears to be a reasonable remedy when it is impossible to establish the subjective intention of the author or those re-publishing the problematic content.

When it comes to the definition of electoral disinformation, from the Convention standpoint it is not absolutely necessary to include it in the positive legal framework concerning summary judicial examination. As the Polish example shows, in the specific model of these proceedings, the simple notion of "false information" can be applied. One of the main conclusions of the first section of this Article was that the defining element of disinformation is individual or collective harm. Enabling a candidate or political party to initiate court proceedings to address false electoral information means that a protected interest exists and is in jeopardy. In this model, harm is therefore of

\footnotetext{
${ }^{83}$ See Smith, supra note 16 , at 77.

${ }^{84}$ See supra note 17 and accompanying text.

${ }^{85}$ See Delfi AS v. Estonia, App. No. 64569/09, paras. 148-49 (June 6, 2015), http://hudoc.echr.coe.int/eng?i=001-155105 (noting the degrees of possible anonymity on the internet).
} 
an individual nature, as false information affects a candidate's rights, but also indirectly influences the public's decision-making process, as false information is disseminated and disorients voters. If the judicial proceeding is of an in abstracto nature, a definition of electoral disinformation should be included. As seen in the French context, its adequate construction is crucial for the assessment of the proportionality of interference. The definition provided for in in abstracto proceedings should therefore focus on the element of harm and must target the most problematic forms of electoral disinformation, namely, deliberate and mass dissemination of false information using artificial or automatic means.

Nonetheless, in both cases there should be some initiative to launch judicial proceedings. It is hard to imagine that in a democratic state the truth of electoral information would be assessed ex officio by public authorities. It would impose an impossible and disproportionate burden and could lead to the discriminatory application of such provisions. In other words, there should be an external initiative in the preliminary phase, although subsequently the proceeding can be either of a specific nature, with the direct participation of an affected candidate or political party, or of an in abstracto nature, when the court makes an abstract assessment of whether there is mass dissemination of false information that negatively influences electoral processes.

Similarly, in both types of judicial electoral proceedings, the court examines the falsity or truthfulness of the facts, not value judgments. According to well-established ECtHR case law, the truth of value judgements is not susceptible of proof, whereas the existence of facts can be demonstrated. ${ }^{86}$ Consequently, proving the truth of a value judgment concerning political or electoral issues is simply impossible. Moreover, the general idea of summary proceedings is to provide truthful information about candidates or political parties, which can then serve as the basis for voters as they form their own political opinions. Authorities' rulings must also not be substitutes for individual discernment as citizens form their value judgments before election day. In this respect, the public task should only be to guarantee the truthfulness of information and leave its evaluation to voters.

With regard to sanctions, the main consequence of a court's conclusion that electoral information is false should be the prohibition of its further dissemination and/or an obligation to rectify it by publishing a statement or an apology. The latter is obviously possible only if the author of the disinformation is known, so it is difficult to imagine its applicability in the in abstracto model, which is aimed at anonymous and mass dissemination of false information. Nonetheless, a court's order to take down false electoral content that disturbs a voter's decision-making process, and to stop its spread before the ballot day, cannot be questioned from the Convention standpoint. As far as other types of sanctions are concerned, including those of a financial nature, this is possible, but in these cases scrutiny must be stricter. It is crucial to prevent a chilling effect on the electoral debate. According to the aforementioned strong guarantees on the freedom to engage in political discourse, all participants in electoral debates, including candidates and voters, should not be discouraged from exercising their rights by the threat of excessive sanctions. If there are additional possible sanctions, as in the Polish electoral law, their application must be proportional to the harm caused by the dissemination of the false electoral information. The court should have the possibility to choose between more or less restrictive measures and must always consider the use of the more lenient one. Also, any arbitrariness in the application of the sanctions should be avoided, as it could affect the equality of opportunities of the candidates.

The most problematic aspect of summary judicial proceedings are sanctions that are aimed at the protection of a candidate's personal rights_-individual interests; for example, reputation, as in the Polish model. As indicated above, the rationale of summary judicial proceedings is to guarantee the reliability and fairness of decision-making processes, as well as the truthfulness of electoral information. Harm caused by disinformation can also be individual, although from this perspective, the obligation to rectify false statements and the prohibition of their further

\footnotetext{
${ }^{86}$ See, e.g., Morice v. France, App. No. 29369/10, para. 126 (Apr. 23, 2015), http://hudoc.echr.coe.int/eng?i=001-154265.
} 
dissemination seems to be a sufficient reaction. Claims related to non-pecuniary damages, such as the violation of a candidate's reputation, may be problematic for a court, as they imply procedural burdens. It is hard to imagine how a court in a twenty-four-hour or forty-eight-hour time frame could, at the same time, decide on the truthfulness of the electoral information, apply the proportionate sanction, and provide satisfaction to the injured candidate, after having assessed the scope of the damages. Moreover, from the electoral perspective, it is not necessary to examine the claims related to the individual rights and interests before election day. With regard to the latter, the aggrieved party can always initiate ordinary proceedings of a civil nature, where there is no curtailment of procedural rights, and the court is not obliged to make an expeditious examination of the claims and damages. ${ }^{87}$

As far as procedural aspects are concerned, malpractice in Polish electoral law has shown that, in light of the European standard, summary proceedings should not be continued after elections. Their aim is to provide reliable electoral information and guarantee the equality of electoral opportunities. An expeditious examination of allegations is therefore justified by the need to deliver a ruling before the voting day. Under such circumstances, there is no justification for the curtailment of the procedural right, and the case will not have an impact on the electoral campaign. At the same time, this is a further argument as to why there should be separate proceedings for the protection of a candidate's personal rights, as previously mentioned.

Other procedural questions arise concerning the influence of summary proceedings on electoral and campaign silence. As in some European countries, electoral campaigns must end before election day, usually twenty-four hours before. Using this standard, the court should be able to determine exactly when to drop the case: By the end of the campaign or by election day. Similarly, the legal framework should indicate if the rectification of false information-for example, publication of a statement-could be done when the campaign is over, and voters have an opportunity to reflect undisturbed on their political choices.

\section{E. Concluding Remarks}

Because judicial summary proceedings provide only a partial solution to the problem of disinformation, they are not a remedy for all types of electoral abuses. They are insufficient, for instance, when game-changing false information - such as statements about the closure of the polling stations or the length of voting queues - is disseminated by automated and mass means just hours before voting. Similarly, important questions remain unanswered concerning the enforcement of judicial decisions. The prohibition on further dissemination of electoral disinformation, issued by a national court, should be implemented using social media or other internet platforms, usually based in different countries. This brings up the question of quick enforceability in the international digital environment.

As the present analysis shows, summary electoral proceedings cannot be questioned from the Convention standpoint and their implementation on the national level is one example of how to comply with the state's positive obligations. They must be adequately designed, as, on the one hand, states enjoy a margin of appreciation concerning the institutional aspects of the electoral system, and, on the other hand, the strongly protected freedom of political or electoral expression is at stake. As far as legal frameworks are concerned, there is a choice between different models of summary judicial proceedings, as the examples of Polish and French law show. The definition of disinformation also poses a challenge, as it has to avoid vague terms and include the elements of public and individual harm. Both from the theoretical and practical standpoints, any sanctions

\footnotetext{
${ }^{87}$ Jezior shows that in the Polish system it is possible to claim a violation of reputation in summary judicial proceedings and, after the election, initiate ordinary proceedings of a civil nature based on the same allegations. See Jezior, App. No. 31955/11 at paras. 11-22. As such, there is a risk of being held liable twice for the same violation, which is misaligned with the Convention. See supra note 4 and accompanying text.
} 
should be proportionate and aim to rebuild public trust in electoral information. Moreover, a court should always make the distinction between facts and value judgments - the truth of the latter is not susceptible to proof-and know exactly when to discontinue the case.

This analysis has also illustrated that there are other relevant spheres where positive action would eventually be necessary. The current communication ecosystem calls for disclosure and transparency policies, because the lack of transparency in algorithmic decision-making processes increases the asymmetry between the actors, namely, internet platforms and their users or voters. ${ }^{88}$ There is no doubt that public authorities should take positive action in order to reduce this gap. ${ }^{89}$ Similarly, combating electoral disinformation requires that the bots (automated online accounts) be clearly labelled and that users are able to critically analyze the content they produce. ${ }^{90}$ All of these actions must consider the paradigm shift in communication. More attention should be paid not to the power exercised by the state, but to the power exercised by the strong private actors who currently share governance in the digital sphere. ${ }^{91}$ There is a need for "new-school speech regulation" directed at the internet infrastructure, as well as for a new set of social responsibilities to defend democratic values in the digital sphere. ${ }^{92}$

Adam Krzywoń Adjunct Professor at the Law Faculty of the University of Warsaw and Research Fellow at the German Research Institute for Public Administration (FÖV), Speyer.

\footnotetext{
${ }^{88}$ SUNSTEIN, supra note 26 , at 199-201.

${ }^{89}$ Giovanni De Gregorio, From Constitutional Freedoms to the Power of the Platforms: Protecting Fundamental Rights Online in the Algorithmic Society, 11 EUR. J. LEgAL STUd. 65, 92 (2019).

${ }^{90}$ Oscar Sanchez Muñoz, la Regulacion de las Campañas Electorales En la Era Digital: Desinformacion Y Mirosegmentacion En Las Redes Sociales Con Fines Electorales 18 (2020).

${ }^{91}$ Nicolas P. Suzor, Lawless: The Secret Rules That Govern Our Digital Lives 169 (2019).

${ }^{92}$ Jack M. Balkin, Free Speech is a Triangle, 118 Colum. L. Rev. 2011 (2018); Jack M. Balkin, Free Speech in the Algorithmic Society: Big Data, Private Governance, and New School Speech Regulation, 51 U.C. DAVIS L. Rev. 1149 (2018).
}

Cite this article: Krzywoń A (2021). Summary Judicial Proceedings as a Measure for Electoral Disinformation: Defining the European Standard. German Law Journal 22, 673-688. https://doi.org/10.1017/glj.2021.23 